\title{
Adsorption Study of Acid Red 114 and Basic Blue 3 on Sunflower Stalk
}

\author{
Erika Janneth Montes-Alba1, Gabriel de Jesús Camargo-Vargas², \\ Rafael Nikolay Agudelo-Valencia ${ }^{2}$, Germán Eduardo Dévora-Isiordia ${ }^{3 *}$ \\ ${ }^{1}$ Environmental Engineering, Universidad Libre, Bogotá, Colombia \\ ${ }^{2}$ Universidad Libre (Bogotá Branch), Bogotá, Colombia \\ ${ }^{3}$ Instituto Tecnológico de Sonora, Obregón, México \\ Email: erikaj.montesa@unilibrebog.edu.co, gabriel.camargov@unilibrebog.edu.co, rafaeln.agudelov@unilibrebog.edu.co, \\ *german.devora@itson.edu.mx
}

How to cite this paper: Montes-Alba, E.J. de Jesús Camargo-Vargas, G., AgudeloValencia, R.N. and Dévora-Isiordia, G.E. (2019) Adsorption Study of Acid Red 114 and Basic Blue 3 on Sunflower Stalk. Jour nal of Water Resource and Protection, 11, 68-81.

https://doi.org/10.4236/jwarp.2019.111005

Received: November 24, 2018

Accepted: January 18, 2019

Published: January 21, 2019

Copyright () 2019 by author(s) and Scientific Research Publishing Inc. This work is licensed under the Creative Commons Attribution International License (CC BY 4.0)

http://creativecommons.org/licenses/by/4.0/

\begin{abstract}
The aim of this work was to evaluate the sunflower stalk (SS) as an adsorbent in the removal of red acid 114 (AR 114) and basic blue 3 (BB 3) in aqueous solutions, without any physicochemical treatment, where temperature and concentration were the studied variables. The research was developed by using the batch processing mode; the contact time was one hour, with constant agitation of $200 \mathrm{rpm}$ and $\mathrm{pH}$ of $7000 \pm 0.050$, using a central composite design. The adsorbent was characterized through BET, SEM, acid sites and basic sites, charging point, and infrared. The results indicated that the sunflower stalk was a viable and economical alternative for the removal of water that had been contaminated by dyes, showing a better performance for the AR 114 dye, reaching a $71.96 \%$ of removal with respect to the initial load. In addition, the EPI Web software was used to model the environmental performance of colorants.
\end{abstract}

\section{Keywords}

Adsorption, Textile Dyes, Low Cost Adsorbents, SEM, BET, EPI Web

\section{Introduction}

The consumption of dyes in the textile industry presents a great challenge at the environmental level, since it is estimated that $10 \%$ of this total ends up in spills, and depending on the type of dye, it may report even higher percentages. Currently, the producers and users of this industry are interested in the stability and the solidity of the dyes, leading to the continuous production of compounds that are more difficult to degrade after their use [1]. Dyes are compounds that, when 
applied to a substrate, they confer a more or less permanent color; they are applied in solution or dispersion and the substrate must have some affinity for biosorption [2]; furthermore, it must be soluble in the medium of application, usually water, at some point during the coloration process [3]. The treatment of textile fibers with dyes generates an environmental problem that is associated with the presence in the waste water, due to the amounts of dyes that do not fix to the fiber, since the degree of fixation is determined by the textile materials, which normally is in the range of $60 \%-80 \%$ [4], and even $50 \%$ [5]. There is a wide range of dyes: reactive, direct, vat, sulphur, and azoic, and these are classified according to their chemical composition, fabric to be dyed, and degree of fixation, among others [6].

Toxicity studies that have been performed in laboratory mice reveal that the ingestion of textile wastewater causes alterations in the reproductive system and reduces mobility [7]; these effluents have also shown high toxicity through bioassays with Daphnia magna [8], and accumulation of these products in the gills, liver, pancreas and muscle of the rainbow trout "Salmo gairdneri" [9]. The presence of dyes in water bodies reduces the passage of sunlight, which can generate imbalance in aquatic ecosystems and cause unpleasant visual effects in natural landscaping [10].

In order to reduce the problems mentioned before, textile effluents must undergo purification processes before being discharged into natural water bodies. There are several methods for the removal of dyes, and they can be divided into three categories: chemical, physical and biological [11]. The advantages and disadvantages of the previously described methods are shown in Table 1, among them there are five main methods used for the treatment of these contaminated waters: adsorption, oxidation-ozonation, biological treatment, coagulation-flocculation, and membrane separation processes [12] [13] [14]. Due to its high cost and the elimination problems, many of these conventional methods have not been widely applied in the textile industry [15].

In adsorption, activated carbon is utilized as adsorbent, and its use is often limited due to its high cost [16], however, the adsorption technique stands out from the other removal techniques because it is less expensive compared to other methods, simpler, and is able to effectively treat dyes in a more concentrated form [17]. Consequently, a field of research has been opened in recent years, which looking for to evaluate, propose, and solve environmental problems, not only for the treatment of waste water, but also in the best utilization of vegetable waste, materials that have little or no economic value [18].

The sunflower stem is an agricultural residue, resulting from the crops that are destined to the production of oleaginous seeds for the production of vegetal oil. In Colombia, a production of 18 thousand tons of refined sunflower oil was reported for 2001 [19], which is why it becomes an alternative to more expensive processes in the treatment of wastewater. There are a new research using materials carbonaceous materials as adsorbent prepared from sunflower stem for removal of heavy metals and other polluting substances [20] [21] [22]. 
Table 1. Major existing and emerging processes for dye removal.

\begin{tabular}{|c|c|c|c|}
\hline Category & Technology & Advantages & Disadvantages \\
\hline \multirow{7}{*}{$\begin{array}{l}\text { Chemical } \\
\text { methods }\end{array}$} & Oxidation & Fast and efficient process & $\begin{array}{l}\text { High costs due to energy consumption. It requires the } \\
\text { use of chemicals, as for example } \mathrm{H}_{2} \mathrm{O}_{2} \text { as an agent to } \\
\text { activate some of the means }\end{array}$ \\
\hline & $\begin{array}{l}\text { Fenton reactions } \\
\left(\mathrm{H}_{2} \mathrm{O}_{2}+\mathrm{Fe}(\mathrm{II}) \text { sal }\right)\end{array}$ & Appropriate chemical method & Sludge generation \\
\hline & Ozonization & $\begin{array}{l}\text { It can be applied in gaseous form, besides, } \\
\text { it increases the volume of waste water or } \\
\text { sludge }\end{array}$ & Short half-life (20 minutes) \\
\hline & Photochemicals & $\begin{array}{l}\text { There is no sludge production, bad odors } \\
\text { are greatly reduced }\end{array}$ & Sub-product formation \\
\hline & $\begin{array}{l}\text { Sodium Hypochlorite } \\
\qquad(\mathrm{NaOCl})\end{array}$ & $\begin{array}{l}\text { Starts and accelerates the breaking of azo } \\
\text { bonds }\end{array}$ & Release of aromatic amines \\
\hline & Electrochemical destruction & $\begin{array}{l}\text { There is no consumption of chemicals or } \\
\text { sludge formation }\end{array}$ & $\begin{array}{l}\text { Relatively high flow rate leading to a direct reduction } \\
\text { in dye removal }\end{array}$ \\
\hline & $\begin{array}{l}\text { Advanced oxidation } \\
\text { processes }\end{array}$ & $\begin{array}{l}\text { There is no production of sludge, } \\
\text { consumption of few or no chemical, } \\
\text { efficiency for recalcitrant dyes }\end{array}$ & $\begin{array}{l}\text { High costs, by-product formation, technical } \\
\text { restrictions }\end{array}$ \\
\hline \multirow{4}{*}{$\begin{array}{l}\text { Biological } \\
\text { methods }\end{array}$} & Fungal discoloration & $\begin{array}{l}\text { Fungi are able to degrade dyes using the } \\
\text { enzymes }\end{array}$ & $\begin{array}{l}\text { The production of enzyme has also been manifested as } \\
\text { unreliable }\end{array}$ \\
\hline & Other microbial cultures & Decolorization between 24 and 30 hours & $\begin{array}{l}\text { Azo dyes under aerobic conditions are not rapidly } \\
\text { metabolized }\end{array}$ \\
\hline & $\begin{array}{l}\text { Adsorption with microbial } \\
\text { biomass }[14]\end{array}$ & $\begin{array}{l}\text { According to the type of dyes, there is a } \\
\text { particular affinity with certain microbial } \\
\text { species. }\end{array}$ & $\begin{array}{l}\text { Not effective for all dyes, slow process, performance } \\
\text { depends on external factors such as } \mathrm{pH}\end{array}$ \\
\hline & $\begin{array}{l}\text { Anaerobic bioremediation } \\
\text { systems }\end{array}$ & $\begin{array}{l}\text { Allows discoloration of azo dyes and } \\
\text { other water solubledyes }\end{array}$ & Production of methane and hydrogen sulphide \\
\hline \multirow{6}{*}{$\begin{array}{l}\text { Physical } \\
\text { methods }\end{array}$} & $\begin{array}{l}\text { Adsorption on activated } \\
\text { carbon }[12]\end{array}$ & Good removal of the wide range of dyes & $\begin{array}{l}\text { High costs, ineffective with dispersed and vat type } \\
\text { dyes, regeneration is costly and results in loss of } \\
\text { adsorbent, it is not a destructive process }\end{array}$ \\
\hline & Filtration membranes [13] & Removal of all types of dyes & $\begin{array}{l}\text { High concentration of sludge, inefficient for the } \\
\text { treatment of large volumes, limited service life of the } \\
\text { membrane, which generates high costs due to periodic } \\
\text { replacement }\end{array}$ \\
\hline & Ionic exchange & Regeneration: without loss of adsorbent & Not effective for dispersed dyes, economic limitations \\
\hline & Irradiation & Effective oxidation at laboratory scale & Requires a lot of $\mathrm{O}_{2}$ \\
\hline & Electrokinetic coagulation & Economically accessible & $\begin{array}{l}\text { High production of sludge generating problems for } \\
\text { handling and disposal }\end{array}$ \\
\hline & Bioadsorbents & $\begin{array}{l}\text { Economically attractive, regeneration is } \\
\text { not necessary, high selectivity }\end{array}$ & $\begin{array}{l}\text { May or may not require chemical modification, and it } \\
\text { generates solid residues }\end{array}$ \\
\hline
\end{tabular}

The objective of this study was to evaluate the potential of the sunflower stalk (SS) for the elimination of AR 114 and BB 3, by varying temperature and concentration in the aqueous solution. These colorants are used, as probe molecules, 
in this research due they are used in Colombian textile factories an important field in the Colombian industry and economy.

\section{Materials and Methods}

\subsection{Adsorbate}

The dyes AR 114 and BB 3 were supplied by CECOLOR Ltd., used as adsorbate. The characteristics of the dyes are listed in Table 2.

Distilled and deionized water was used to prepare all the solutions, making use of $50 \mathrm{~mL}$ of water for each test.

\subsection{Preparation and Characterization of the SS as Adsorbent}

The sunflowers stalk (SS) used in this study was obtained in the local market of Bogotá D.C. (Colombia), with the purpose of representing the process of decomposition of the agricultural residue, and ensure the drying in a natural way, the sunflower stems was exposed to ambient conditions (relative humidity 65\%, average temperature $15^{\circ} \mathrm{C}$ ) for a period of two weeks, then the skin was removed and the marrow of the sunflower stem was processed in the industrial mill IKA Universalmühle M20, to finally be sieved collecting the material retained in the 200 mesh. The particle size to be worked was 850 microns. The SS sample that was prepared, was stored in an airtight container for later use. The SS was not modified with any physical-chemical treatment prior to the adsorption experiments. The textural characterization of the SS was performed under a standard procedure in a Quantachome Autosorb Automated Gas Sortion equipment, using $77 \mathrm{~K}$ Nitrogen and generating a total of 21 measurement points with which the surface area was determined using the BET model. The superficial functional groups of SS were detected by infrared with the Fourier transform infrared spectroscopy (FTIR) in the FTIR-2000 spectrophotometer, PerkinElmer. The spectra were recorded $4000-400 \mathrm{~cm}^{-1}$. The surface morphology of GP porosity was determined by using scanning electron microscopy (SEM) on the Hitachi Tabletop Microscope TM3030. The acidity and total basicity of the sunflower stem were determined by the Boehm method [23].

\subsection{Study of Adsorption in Discontinuous Mode (Batch)}

In order to perform the adsorption study, a central composite design type experiment was used and analyzed, evaluating the concentration variables between 50 and $100 \mathrm{ppm}$ and temperature between $25^{\circ} \mathrm{C}$ and $40^{\circ} \mathrm{C}$; the following fixed variables were established for the experiments, which were carried out by adding a fixed amount of SS $(0.25 \mathrm{~g})$ to a series of $100 \mathrm{ml}$ beakers with $50 \mathrm{ml}$ of diluted solutions $(50-100 \mathrm{mg} / \mathrm{L})$ for each one of the dyes AR 114 and BB 3. The solutions were placed on the plate with temperature control $\left(25^{\circ} \mathrm{C}-40^{\circ} \mathrm{C}\right)$ and agitation, from the brand IKA Werke RT 15 power, they were shaken at $200 \mathrm{rpm}$ with a time of contact of one hour and $\mathrm{pH}$ of $7000 \pm 0.050$, the $\mathrm{pH}$ is adjusted to each solution with $1.0 \mathrm{M} \mathrm{KOH}$ and $1.0 \mathrm{M} \mathrm{HCl}$. At the end of the process, the final 
Table 2. Properties and characteristics of dyes AR 114 and BB 3.

\begin{tabular}{|c|c|c|c|}
\hline Generic name & Acid Red 114 & Generic name & Básico Azul 3 \\
\hline $\begin{array}{l}\text { Chemical name } \\
\text { (IUPAC) }\end{array}$ & $\begin{array}{l}\text { Disodium 8-((3,3'-dimetthyl-4'-((4-((4- } \\
\text { methylphenyl) sulphonyl) oxy) phenyl) } \\
\text { azo)-(1,1'-biphenyl)-4-yl) azo)- } \\
\text { 7-hydroxy-1,3-naphthalenedisulphonate }\end{array}$ & Chemical name (IUPAC) & $\begin{array}{c}\text { 3,7bis(diethylamino)phenoxazin-5-ium } \\
\text { chloride }\end{array}$ \\
\hline Molecular formula & $\mathrm{C}_{37} \mathrm{H}_{28} \mathrm{~N}_{4} \mathrm{O}_{10} \mathrm{~S}_{4} \mathrm{Na}_{2}$ & Molecular formula & $\mathrm{C}_{2} \mathrm{H}_{26} \mathrm{~N}_{3} \mathrm{O}_{10} \mathrm{OCl}$ \\
\hline Molecular weight & $830.8 \mathrm{~g} / \mathrm{mol}$ & Molecular weight & $359.89 \mathrm{~g} / \mathrm{mol}$ \\
\hline CAS number & $6459-94-5$ & CAS number & $33203-82-6$ \\
\hline Colour index number & 23,635 & Colour index number & 51,004 \\
\hline & Molecular structure & \multicolumn{2}{|c|}{ Molecular structure } \\
\hline & $a_{0}^{0}$ & $\mathrm{H}_{3} \mathrm{C}$ & $\mathrm{CH}_{3}$ \\
\hline
\end{tabular}

concentration of dye in the solution was measured at maximum wavelengths for AR $114(526 \mathrm{~nm})$ and BB $3(655 \mathrm{~nm})$ using a spectrophotometer. The percentage of removal is calculated from the following equation:

$$
\% \text { of removal }=\frac{(\text { Initial concentration }- \text { Final concentration })}{\text { Initial concentration }} * 100
$$

\subsection{Balance Study}

It is from the analysis of results and the determination of the optimum point for the variables and conditions that have been established in the adsorption study in discontinuous mode, that the equilibrium study was performed. The amount of remaining dye from the adsorption at equilibrium $q_{e}(\mathrm{mg} / \mathrm{g})$ is calculated from the following equation:

$$
q_{e}=\frac{\left(C_{o}-C_{e}\right) V}{W}
$$

where $C_{o}$ is the initial concentration of the liquid phase and $C_{e}(\mathrm{mg} / \mathrm{L})$ is the concentration of the liquid phase in equilibrium, $V(\mathrm{~L})$ is the volume of the solution and $W(\mathrm{~g})$ is the mass of the adsorbent that was used.

The adsorption isotherm indicates how the adsorbate molecules are distributed between the liquid phase and the solid phase when the adsorption process reaches a state of equilibrium. The analysis of the isothermal data by equipping them for different isothermal models is an important step in finding the appropriate model that can be used for the objective design [24]. The isotherm data were fitted to the Langmuir and Freundlich isotherms.

The Langmuir isotherm is represented by the following linearized equation:

$$
\frac{C_{e}}{q}=\frac{1}{q_{e} * b}+\frac{C_{e}}{q_{e}}
$$


where $q$ is the adsorption capacity (meq. $\left.\mathrm{g}^{-1}\right), C_{e}$ is the solute equilibrium concentration in the solution, $q_{e}$ is the maximum adsorption capacity (meq. $\left.\mathrm{g}^{-1}\right), b$ is the Langmuir constant.

The Freundlich isotherm is represented by the following linearized equation:

$$
\log q=\log K_{f}+\frac{1}{n} * \log C_{e}
$$

where $q$ (meq. $\left.\mathrm{g}^{-1}\right)$ is the capacity of adsorption or capture of ions by the adsorbent, $C_{e}$ is the concentration of sorbate in the solution when the equilibrium is reached, $K_{f}$ is the biosorption capacity expressed in meq. $\mathrm{g}^{-1}$ and $1 / n$ is the biosorption intensity.

\subsection{Kinetic Study}

The procedure for the kinetic test is basically identical to the procedure for the equilibrium tests. The aqueous samples were taken at pre-set time intervals (1 min - $120 \mathrm{~min}$ ) and the dye concentrations were similarly measured. The amount of adsorption at $t$ time in $(\mathrm{mg} / \mathrm{g})$ was calculated by using the following equation:

$$
q_{t}=\frac{\left(C_{o}-C_{t}\right) V}{W}
$$

The kinetic behavior of the adsorption process for the dyes AR 114 and BB 3 was analyzed by the use of the pseudo-first order, pseudo-second order, and intra-particle diffusion models [25]. The linear form of the pseudo-first order equation is given by:

$$
\log \left(q_{e}-q_{t}\right)=\frac{\log \left(q_{e}\right)-k_{1} * t}{2.303}
$$

The linear form of the pseudo-second order equation is given by:

$$
\frac{t}{q_{t}}=\frac{1}{k_{2} * q_{e}^{2}}+\frac{t}{q_{e}}
$$

The constant of velocity for the intraparticle diffusion model $\left(k_{d}\right)$ is given by Weber and Morris [23]

$$
q_{t}=k_{p} * t^{0.5}+C
$$

where $q_{t}$ are the amounts of dye that are adsorbed on adsorbent at various times $t(\mathrm{mg} / \mathrm{g}), k_{1}$ is the velocity constant of the kinetic first order pseudo-equilibrium $\left(\mathrm{min}^{-1}\right), t$ is the contact time ( $\left.\mathrm{min}\right), k_{2}$ is the equilibrium velocity constant of the pseudo-second order kinetics $(\mathrm{g} /(\mathrm{mg} \cdot \mathrm{min})), k_{p}$ is the intraparticle diffusion velocity constant $\left(\mathrm{mg} /\left(\mathrm{g} \cdot \mathrm{mín}^{1 / 2}\right)\right)$ and $C(\mathrm{mg} / \mathrm{g})$ is a constant.

\section{Results and Discussion}

\subsection{Characterization of the SS as an Adsorbent}

The textural characterization by BET for the sunflower stem was in specific area $\left(\mathrm{m}^{2} / \mathrm{g}\right)$ of 7170 , the volume of pores of $\left(\mathrm{cm}^{3} / \mathrm{g}\right) 2548 \times 10^{-3}$ and the diameter of 
pores $(\mathrm{nm})$ 15, 78. According to the results, the area is relatively low if compared with commercial materials such as bone charcoal $\left(104 \mathrm{~m}^{2} / \mathrm{g}\right)$, or activated alumina $\left(190 \mathrm{~m}^{2} / \mathrm{g}\right)$, which limits the intraparticle adsorption. According to the literature, the pore diameter for SS is classified as mesopores $(2<$ pore diameter $<$ $50 \mathrm{~nm}$ ) [26]. The Fourier transform infrared spectroscopy (FTIR) that is shown in Figure 1, where the spectrum illustrates a series of absorption peaks that also evidence the complex character of the material that is being examined. The FTIR analysis indicates vibration of the $\mathrm{O}-\mathrm{H}$ bond originating from the lignin at 3330 $\mathrm{cm}^{-1}$; a symmetrical vibration of the $\mathrm{CH}_{3}$ bond originating from the ether of the lignin at $2936 \mathrm{~cm}^{-1}$; at $2340 \mathrm{~cm}^{-1}$, a weak signal produced by the vibration of the $\mathrm{C}-\mathrm{O}$ bond of the acetal; at $1601 \mathrm{~cm}^{-1}, \mathrm{R}-\mathrm{CH}_{3}$ symmetrical deformation of the $\mathrm{C}-\mathrm{H}$ bond; and narrow vibration of the $\mathrm{O}-\mathrm{H}$ bond at $668 \mathrm{~cm}^{-1}$.

Figure 2 presents two SEM microphotographs of the sunflower stem without dye, at different scales $(1 \mathrm{~mm}$ and $10 \mu \mathrm{m})$, making it possible to corroborate the low specific area $\left(7170 \mathrm{~m}^{2} / \mathrm{g}\right)$, due to its low porous distribution.

The determination of acid and basic sites in the sample shows that the TG surface charge is distributed approximately in $60 \%$ of acid sites or active sites of acidic nature (1.46 meq. $\mathrm{g}^{-1}$ ) and the remaining $40 \%$ with basic sites $(0.91$ meq. $\left.\mathrm{g}^{-1}\right)$. On the other hand, the zero-charge point for the biosorbent presented a valu e of 5.4; in other words, the material is slightly acidic so that it can accept or yield protons, and it has the ability to adsorb dyes of the acid or basic type.

\subsection{Effects of the Initial Concentration of Dye and Temperature}

According to the analysis of results of the design of experiments, the graphs of surface that determine the behavior of the dyes under the conditions previously established are presented below.

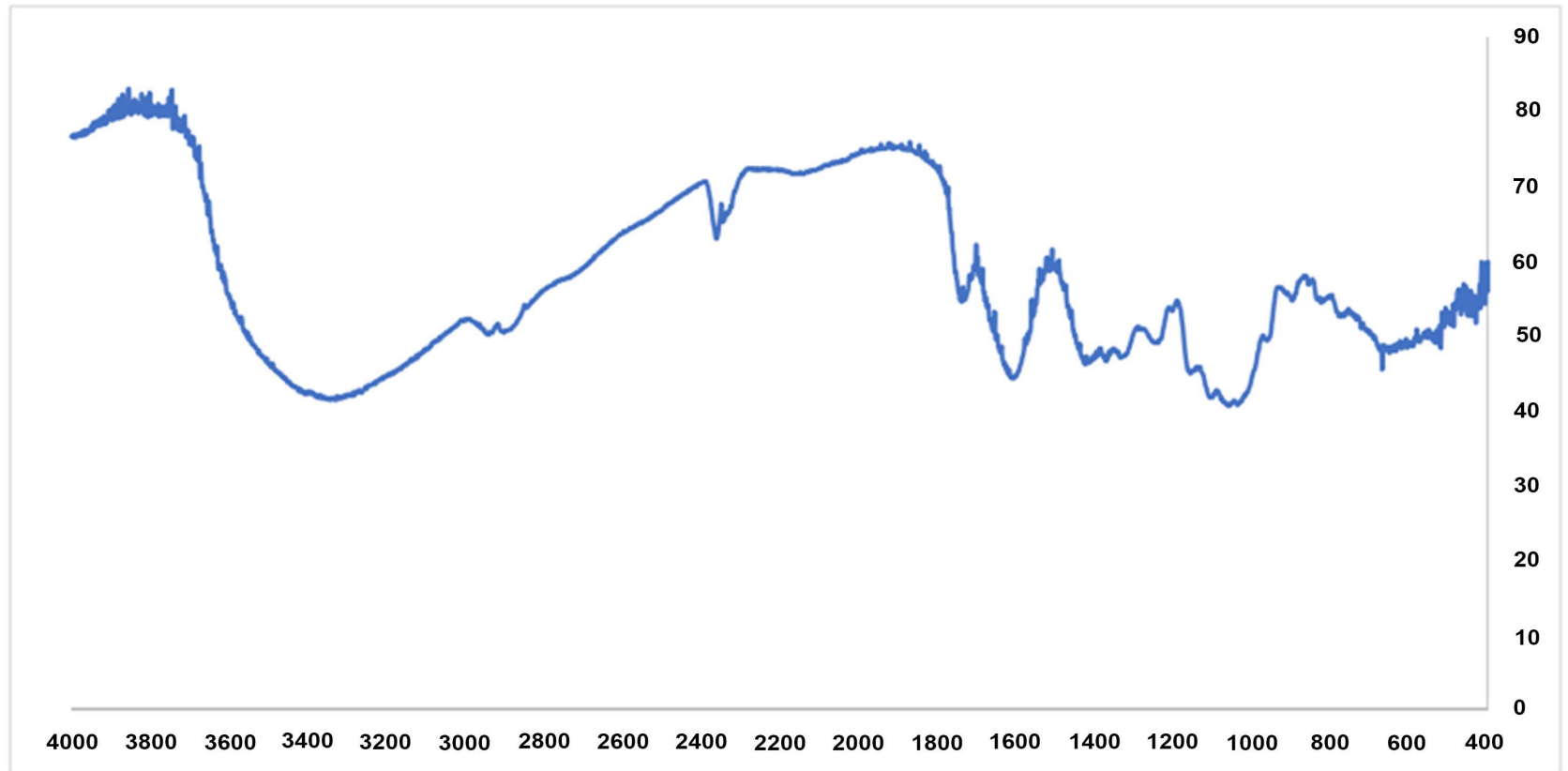

Figure 1. Infrared spectrum for the SS. 

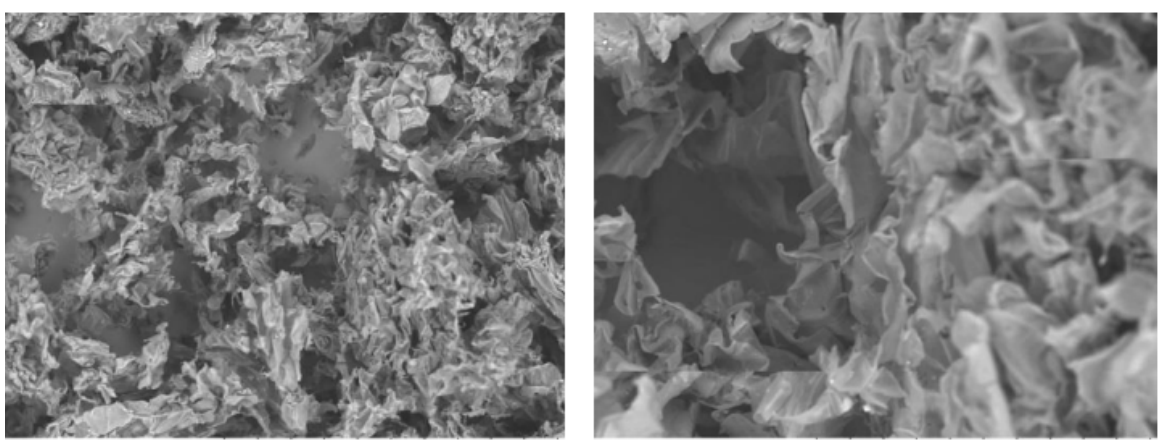

Figure 2. SEM microphotographs sunflower stem.

Figure 3 shows the response surface for the percentage of removal, depending on the concentration and temperature variables. The graph allows seeing how the temperature has a marked influence on the percentage of removal for low concentrations of the colorant in solution, an effect that is lost when the temperature of the dye increases. The maximum removal reached was $71.952 \mathrm{ppm}$ and was presented for a dye concentration of $83 \mathrm{ppm}$ and $25^{\circ} \mathrm{C}$.

Figure 4 allows to see the trend of the response variable percentage of removal with respect to the factors of initial concentration of dye and temperature of the process, with respect to the influence of the temperature it is seen that, at low concentration and higher temperature, the removal of dye reaches the highest value, likewise, as the initial concentration of dye increases the percentage of removal decreases. The percentage of removal for these trials varied between $25.675 \%$ and $59.404 \%$.

\subsection{Balance Study}

The statistical analysis of the adjustment of the experimental data showed a higher degree of correlation with the Freundlich isotherm in both dyes; as it can be seen in Table 3.

This indicates that the adsorption of the dyes is presented in adsorbent monolayers, where the surface of the adsorbent is energetically heterogeneous [27], in which the mass of the solute adsorbed on the adsorbent continues to increase when the concentration of the solute in the equilibrium is elevated, and does not become asymptotic at high concentrations. The Freundlich isotherms generated for the dyes AR 114 and BB 3 are presented in Figure 5 and Figure 6.

\subsection{Kinetic Study}

The results for the adjustment of the experimental data to the three kinetic models are presented in Table 4.

From the values above, it can be observed that the highest degree of correlation is presented for a pseudo-second order kinetics, for the two dyestuffs object of study (Figure 7), which allows to establish that the adsorption velocity will be favored by high values of the variable of concentration, which in turn was favored by the mass transfer [28]. 


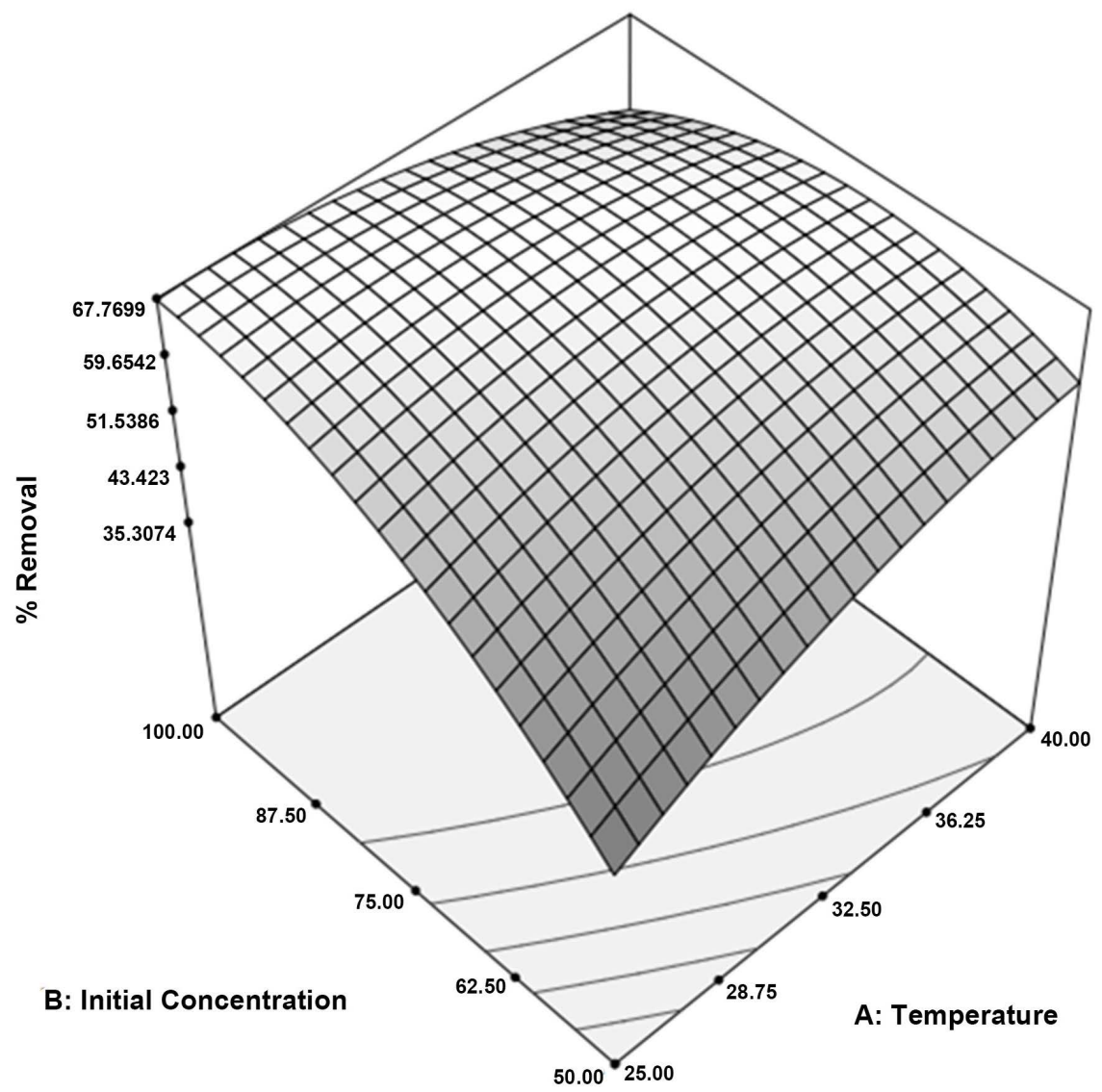

Figure 3. Response surface acid red 114.

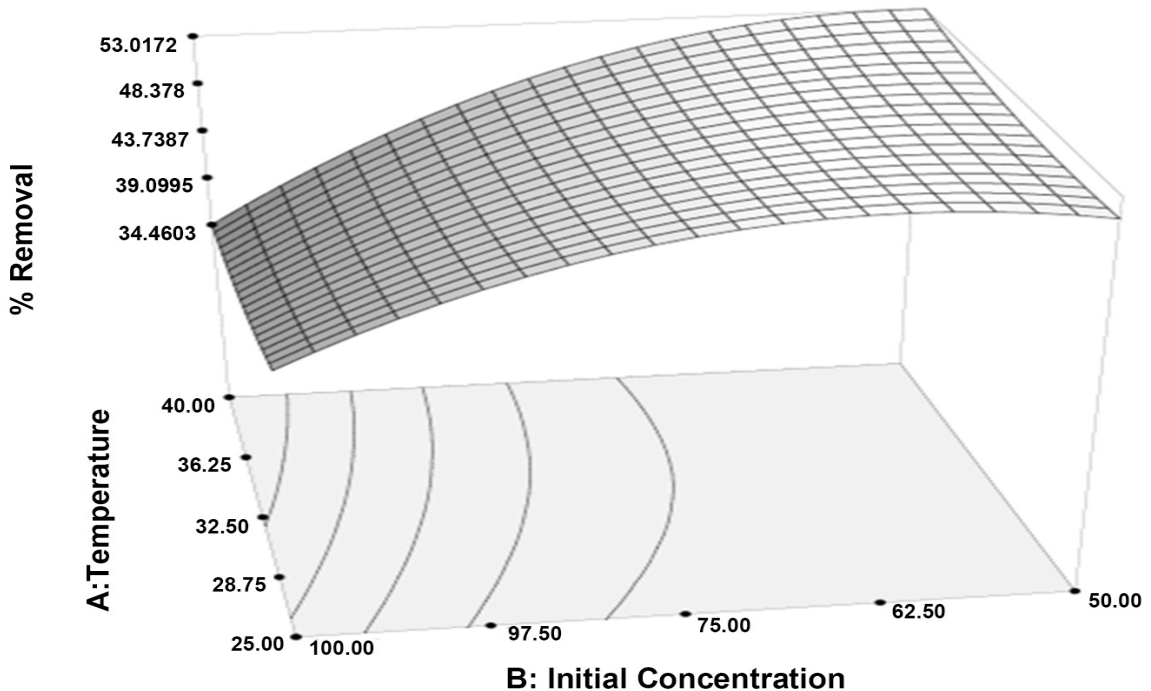

Figure 4. Response surface basic blue 3.

According to Bhatnagar [29], in the case of agricultural waste materials without prior treatment generally they have a maximum capacity of "qmax", which varies from $1.6 \mathrm{mg} / \mathrm{g}$ (coconut marrow) to $68.03 \mathrm{mg} / \mathrm{g}$ (peanut shell) in the removal of acid or basic dyes, in the present paper, the maximum adsorption 
Table 3. Correlation of the experimental data with the Freundlich model.

\begin{tabular}{ccc}
\hline Dye & Freundlich & $\mathbf{R}^{2}$ \\
\hline AR 114 & $q=0.079 * C_{e}^{1.258}$ & 0.953 \\
BB 3 & $q=0.004 * C_{e}^{2.093}$ & 0.974 \\
\hline
\end{tabular}

Table 4. Constants for the different kinetic models.

\begin{tabular}{cccc}
\hline Kinetic model & & AR 114 & BB 3 \\
\hline & $q_{\mathrm{e}}\left(\mathrm{meq} \cdot \mathrm{g}^{-1}\right)$ & 0.435 & 13.458 \\
Pseudo-first order & $k_{1}\left(\mathrm{~min}^{-1}\right)$ & 43.918 & 0.518 \\
& $R^{2}$ & 0.740 & 0.864 \\
Pseudo-second order & $q_{e}\left(\mathrm{meq} \cdot \mathrm{g}^{-1}\right)$ & 9.936 & 4.918 \\
& $k_{2}\left(\mathrm{~g} \cdot \mathrm{meq}^{-1} \cdot \mathrm{min}^{-1}\right)$ & 0.098 & 0.413 \\
& $\mathrm{R}^{2}$ & $\mathbf{0 . 9 9 9}$ & $\mathbf{0 . 9 9 6}$ \\
& $k_{p}\left(\mathrm{meq} \cdot \mathrm{g}^{-1} \cdot \mathrm{h}^{-0,5}\right)$ & 1.148 & 0.556 \\
Intraparticle diffusion models & $C$ & -6.051 & -0.284 \\
& $R^{2}$ & 0.951 & 0.546 \\
\hline
\end{tabular}

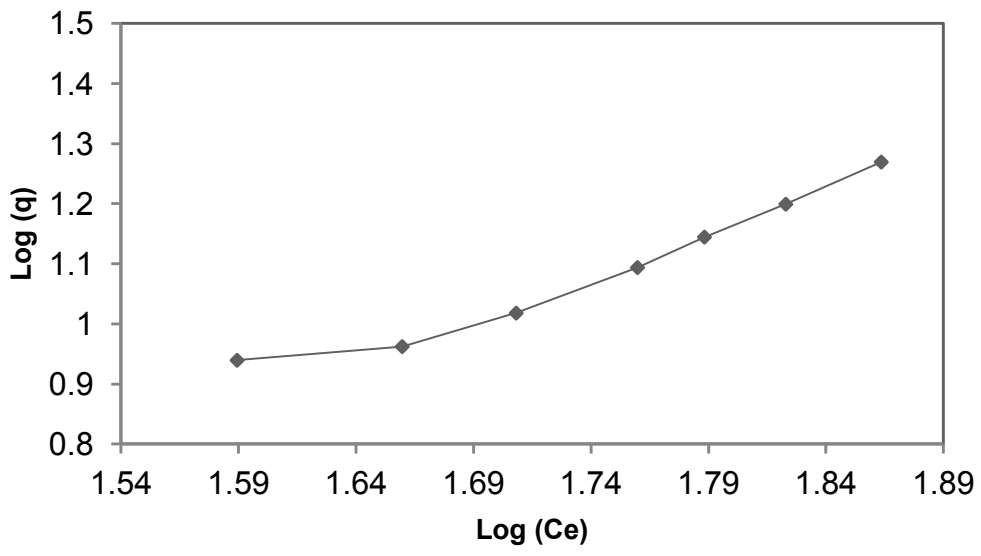

Figure 5. Freundlich isotherm for dye AR 114 on SS.

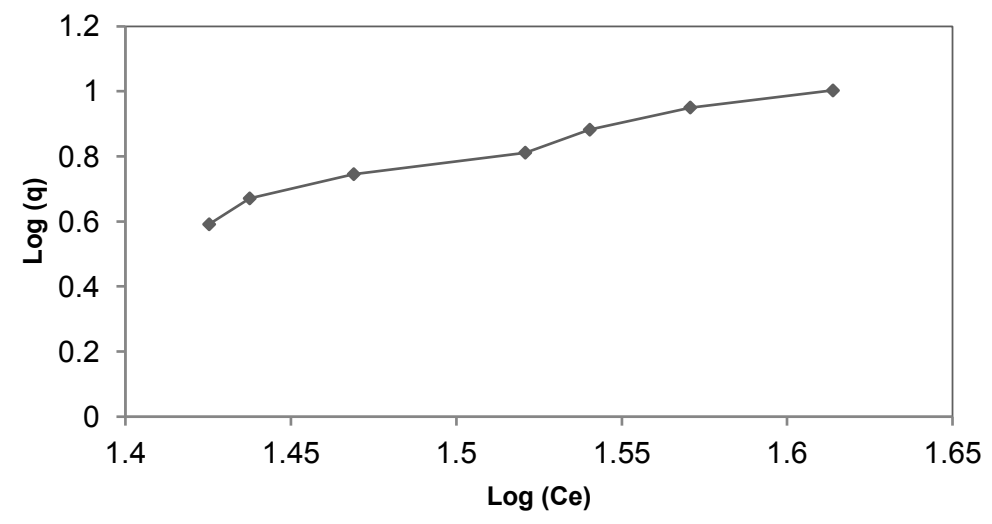

Figure 6. Freundlich isotherm for dye BB 3 on SS. 


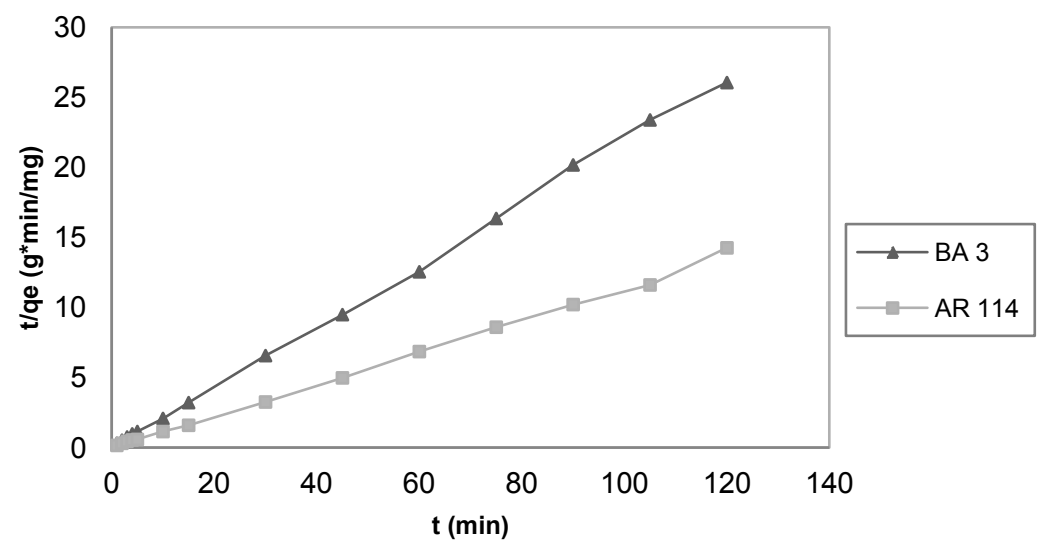

Figure 7. Linearization of the data according to the kinetic model of pseudo-second order for dyes AR 114 and BB 3.

capacity for the Red Acid 114 dye is $9936 \mathrm{mg} / \mathrm{g}$, and for the Basic Blue 3 dye is $4918 \mathrm{mg} / \mathrm{g}$, which transforms the studied material into a potential adsorbent for these dyes.

\subsection{Evaluation of Environmental Parameters}

The software that was used for this purpose was the EPIWEB 4.1, supervised and developed by the United States Environmental Protection Agency (EPA), in which qualitative and quantitative methods are presented in order to estimate the environmental performance of a chemical when the only information that may be available is that of its chemical structure. Molecular properties are frequently used in the environmental performance assessment; these are the Henry's law constants, octanol-water partition coefficient, water solubility, soil absorption coefficients, and bioconcentration factors. The methods that are described in the program are generally defined as methods of group contribution or Structure Activity Relationships (SARs), or Quantitative Structure Activity Relationships (QSARs) [30]. Some properties that are relevant to the research are shown in Table 5.

According to the evaluation of the environmental performance, the dyes that were studied have low rates of degradation in liquid phase and a high fixation in soils, which highlights the importance and the relevance of the use of the adsorption as a treatment method for water that has been contaminated by dyes.

\section{Conclusions}

The characterization of the adsorbent was found predominance of acid sites 1.46 (meq/g), on the basics $0.92(\mathrm{meq} / \mathrm{g})$; the determination of the $\mathrm{pH}$ at the point of zero charge presented a value of 5.40; the textural characterization showed a specific area of the sunflower stem of $7170 \mathrm{~m}^{2} / \mathrm{g}$, which was corroborated by Scanning Electron Microscopy (SEM). The optimum parameters of the adsorption study for the Red Acid dye were concentration of $83 \mathrm{ppm}$ and temperature of $25^{\circ} \mathrm{C}$, and for the Basic Blue 3 dye, concentration of $50 \mathrm{ppm}$ and temperature 
Table 5. Properties evaluated for AR 114 and BB 3.

\begin{tabular}{ccc}
\hline Property & AR 114 & BB 3 \\
\hline $\begin{array}{c}\text { Water partition coefficient } \\
\text { (KOWWIN v1.68 estimate) }\end{array}$ & Low (3.08) & Low (0.28) \\
$\begin{array}{c}\text { Rapid probability of degradation } \\
\text { (BIOWIN v4. 10) }\end{array}$ & $\begin{array}{c}2.47 \text { weeks } \\
\text { NO }\end{array}$ & $\begin{array}{c}\text { 3.11 weeks } \\
\text { NO }\end{array}$ \\
$\begin{array}{c}\text { Coefficient of soil adsorption } \\
\text { (KOCWIN v2 00): (MCI method) }\end{array}$ & Very strong (8.23) & Very strong (5.24) \\
\hline
\end{tabular}

of $25^{\circ} \mathrm{C}$. The analysis of the central composite design showed that there were significant effects on the temperature variable on the removal percentage; the variables that were studied presented a higher percentage of adsorption for the Red Acid 114 dye (71.96\%) with respect to the Basic Blue 3 dye (59.40\%). The equilibrium of the process is adjusted to the Freundlich model with a maximum adsorption capacity of $9936 \mathrm{mg} / \mathrm{g}$ for Acid Red 114, and $4918 \mathrm{mg} / \mathrm{g}$ for Basic Blue 3, evidencing that the sunflower stalk is a good adsorbent for the removal of dyes.

The adsorbents used in this research are useful for the colorants removal and future investigations will be developed in pilot scale and preparing activated carbon from sunflower stem with functionalizing the carbonaceous material obtained

\section{Acknowledgements}

Authors extend their appreciation to the Universidad Libre Seccional Bogotá D.C. (Colombia), for the technical and financial support for the development of this research.

\section{Conflicts of Interest}

The authors declare no conflicts of interest regarding the publication of this paper.

\section{References}

[1] Keith, K.H., et al. (1999) Sorption of Acid Dyes from Effluents Using Activated Carbon. Resources, Conservation and Recycling, 27, 57-71. https://doi.org/10.1016/S0921-3449(98)00085-8

[2] Ramos, J. (2010) Estudio del proceso de biosorción de colorantes sobre borra (Cuncho) de café. Trabajo de grado. Maestría en Ciencia-Química, Universidad Nacional de Colombia, Bogotá, 1-65.

[3] Broadbent, A.D. (2001) Basic Principles of Textile Coloration. Society of Dyers and Colourists, Bradford, 26.

[4] Odintsova, I.O., Krotova, M.N. and Mel'nikov, B.N. (2009) Use of Cationic Agents for Fixing Coloration of Textile Materials. Russian Journal of Applied Chemistry, 82, 461-465. https://doi.org/10.1134/S1070427209030215

[5] Mohan, N., Balasubramanian, N. and Basha, C.A. (2007) Electrochemical Oxidation of Textile Wastewater and Its Reuse. Journal of Hazardous Materials, 147, 644-651. 
https://doi.org/10.1016/j.jhazmat.2007.01.063

[6] Society of Dyers and Colourists Classification of Dyes. http://dyes-pigments.standardcon.com/what-is-dye.html

[7] Suryavathi, V., et al. (2005) Acute Toxicity of Textile Dye Wastewaters (Untreated and Treated) of Sanganer on Male Reproductive Systems of Albino Rats and Mice. Reproductive Toxicology, 19, 547-556. https://doi.org/10.1016/j.reprotox.2004.09.011

[8] Verma, Y. (2008) Acute Toxicity Assessment of Textile Dyes and Textile and Dye Industrial Effluents Using Daphnia Magna Bioassay. Toxicology and Industrial Health, 24, 491-500. https://doi.org/10.1177/0748233708095769

[9] Riva, C., et al. (1988) Biodegradabilidad, toxicidad y acumulación del colorante acido azul omegacromo en la trucha arco iris "Salmo gairdneri”. Boletin Intextar, 1, 55-70.

[10] Ministerio de medio ambiente, dirección general de calidad y evaluación ambiental (2004) Guía de Mejores Técnicas Disponibles en España del sector textil. Centro de Publicaciones Secretaria General Técnica Ministerio de Mediop, España, 39.

[11] Robinson, T., et al. (2001) Remediation of Dyes in Textile Effluent: A Critical Review on Current Treatment Technologies with a Proposed Alternative. Bioresourse Tecnology, 77, 274-255. https://doi.org/10.1016/S0960-8524(00)00080-8

[12] Dévora-Isiordia, G.E., González, R. and Ruiz, S. (2013) Evaluación de procesos de desalinización y su desarrollo en México. Tecnología y Ciencias del Agua, 4, 27-46.

[13] Dévora-Isiordia, G. E., Robles Lizárraga, A., Fimbres Weihs, G.A. and Álvarez Sánchez, J. (2017) Comparación de métodos de descarga para vertidos de salmueras, provenientes de una planta desalinizadora en Sonora, México. Revista Internacional de Contaminación Ambiental, 33, 45-54. https://doi.org/10.20937/RICA.2017.33.esp02.04

[14] Osma, J.F., et al. (2007) Sunflower Seed Shells: A Novel and Effective Low-Cost Adsorbent for Removal of Diazo Dye Reactive Black 5 from Aqueous Solutions. Journal of Hazardous Materials, 147, 900-905. https://doi.org/10.1016/j.jhazmat.2007.01.112

[15] Crini, G. (2006) Non-Conventional Low-Cost Adsorbents for Dyes Removal: A Review. Bioresource Technology, 97, 1061-1085.

[16] Thinakaran, N., et al. (2008) Removal of Acid Violet 17 from Aqueous Solutions by Adsorption onto Activated Carbon Prepared from Sunflower Seed Hull. Journal of Hazardous Materials, 151, 316-322. https://doi.org/10.1016/j.jhazmat.2007.05.076

[17] Thinakaran, N., et al. (2008) Equilibrium and Kinetic Studies in the Removal of Acid Red 114 from Aqueous Solutions Using Activated Carbons Prepared from Seed Shells. Journal of Hazardous Materials, 158, 142-150. https://doi.org/10.1016/j.jhazmat.2008.01.043

[18] Arvanitoyannis, I.S. and Varzakas, T.H. (2008) Vegetable Waste Management: Treatment Methods and Potential Uses of Treated Waste. Waste Management for the Food Industries. Elsevier Inc., New York, 703-761.

[19] Ministerio de agricultura y desarrollo rural, observatorio agrocadenas colombia (2005) La cadena de las oleaginosas en Colombia. Bogotá, 12.

[20] Roman, S., et al. (2013) Production of Low-Cost Adsorbents with Tunable Surface Chemistry by Conjunction of Hydrothermal Carbonization and Activation Processes. Microporous and Mesoporous Materials, 165, 127-133.

[21] Jain, M., Gark, V.K., Kadirvelu, K. and Sillampa, M. (2016) Adsorption of Heavy 
Metals from Multi-Metal Aqueous Solution by Sunflower Plant Biomass-Based Carbons. International Journal of Environmental Science and Technology, 13, 493-500. https://doi.org/10.1007/s13762-015-0855-5

[22] Jain, M., Gark, V.K. and Kadirvelu, K. (2009) Chromium (VI) Removal from Aqueous System Using Helianthus annuus (Sunflower) Stem Waste. Journal of Hazardous Materials, 162, 365-372. https://doi.org/10.1016/j.jhazmat.2008.05.048

[23] Boehm, H.-P. (2008) Chapter Thirteen: Surface Chemical Characterization of Carbon from Adsorption Studies. In: Adsorption by Carbons, Elsevier Ltd., New York, 301-323.

[24] Duong, D. (1998) Adsorption Analysis: Equilibria and Kinetics. Imperial College Press, Vol. 2, 11.

[25] Agudelo, N. and Husserl, J. (2013) Evaluación de la remoción de sales disueltas presentes en agua de producción sintética por medio del uso de fibras de Furcraea bedinghausii (fique) modificadas químicamente. Trabajo de grado, Maestría en Ingeniería Ambiental. Universidad de los Andes, Bogotá.

[26] Leyva, R. (2007) Importancia y aplicaciones de la adsorción en fase liquida. In: Moreno, J.C., Ed., Sólidos porosos, preparación, caracterización y aplicaciones, EdicionesUniandes, 157-168.

[27] Srivastava, S. and Goyal, P. (2010) Novel Biomaterials, Decontamination of Toxic Metals from Wastewater. Springer-Verlag, Berlin, Heidelberg.

[28] Allen, S.J., et al. (2005) Kinetic Modeling of the Adsorption of Basic Dyes by Kudzu. Journal of Colloid and Interfase Science, 286, 101-109. https://doi.org/10.1016/j.jcis.2004.12.043

[29] Bhatnagar, A. and Sillanppa, M. (2010) Utilization of Agro-Industrial and Municipal Waste Materials as Potencial Adsorbents for Water Treatment-A Review. Chemical Engineering Journal, 157, 277-296. https://doi.org/10.1016/j.cej.2010.01.007

[30] Allen, D. (2001) Green Engineering: Environmentally Conscious Design of Chemical Processes. Pearson Education, London. https://doi.org/10.1002/aic.690470902 